\title{
The Application of PAIKEM Approach to the Subject of Christian Education and Character Education to Improve the Learning Outcomes of the Grade 3 Students in SD GMIM 1 Manado
}

\author{
Sugijanti Supit \\ IAKN Manado \\ Supitsugiyati27@gmail.com
}

\begin{abstract}
The research about the application of PAIKEM approach which applied at SD GMIM 1 Manado was made with the purpose to improve the learning outcomes of the students as they learn about Christian Education subject by using the methods of Classroom Action Research. This method has two cycles which start from planning, action, observation, dan reflection. PAIKEM approach is used for this research with 22 grade 3 students in SD GMIM 1 Manado as the subject. The result of the first cycle of teacher observation on the first meeting was $58,33 \%$ and on the second meeting was $66,66 \%$. On the second cycle shows improvement, on the first meeting it was $83,33 \%$ and rise to $91,66 \%$ on the second meeting. The result of student observation on the first cycle was $54,16 \%$ and in the second meeting, it was $62,5 \%$. On the second cycle, the percentage was $87,5 \%$. This improved in the second meeting with the percentage of $95,83 \%$. On the pre-action step, the percentage of the ability to absorb the fundamental of the lesson shows only $50,45 \%$ with the percentage of minimum criteria of mastery learning was $36,36 \%$. The first cycle on the action process shows the percentage of the ability to absorb the fundamental of the lessons improved to $75,45 \%$ with the percentage of the minimum criteria of mastery learning was $68,16 \%$. Then in the second cycle, it improves with the percentage of $92,27 \%$ and with the percentage of the minimum criteria of mastery learning was $90,90 \%$. As a conclusion, this research proves that the approach of PAIKEM could be used to improve the learning outcomes on the subject of Christian Education and Character Education in SD GMIM 1 Manado.
\end{abstract}

Keywords: PAIKEM approach, Christian Education, SD GMIM 1 Manado.

\section{Introduction}

Christian Education and Moral education both are subjects that need to be added into the curriculum in Elementary School level to support the goals of the national education. That is why to reach that goal both of these subjects need to be taught using an active, innovative, creative, effective and fun approach, especially for the grade three students.

Teachers in the Elementary School have the responsibility to create a creative and enjoyable learning environment. They should be able to shape the students to develop their cognitive, affective and psychometrics skills. This can be seen through the result of the learning process of the students as they put on the minimum criteria of mastery learning that applied by the school.

An early observation identified that the result of learning of the grade three students in SD GMIM 1 Manado for these two subjects was still low and didn't meet the minimum criteria of 
mastery learning. The students seem unmotivated in the learning process and it can be seen through their absence which is only $20 \%, 30 \%$ unmotivated to learn these two subjects and $40 \%$ of the students don't even reach the minimum criteria of mastery learning.

AICEF approach has been researched and applied in some schools, just like the research from Novalin Noortje Tomahuw (2014). The hypothesis testing proved that there is a positive correlation between motivation and the result of learning Christian Education lessons through the AICEF approach. The coefficient correlation result was ry $2=0,70$ with the coefficient determination was $\mathrm{r} 2=0,49$. This shows that the motivation of the students in the learning process gives a contribution of $49 \%$ for the result of the outcomes throughout the learning process.

According to the context of Christian Education and Moral Education teaching that found in SD GMIM 1 Manado, then, the researcher comes up with the assumption that the approach that could be used to improve the learning outcomes of Christian Education and Moral Education learning is by creating the learning environment that makes the students more active, innovative, creative, effective and fun, whether for the teacher and the students as well. Therefore, the researcher comes up with this idea to do the classroom action research with the title "The Application of Active, Innovative, Creative, Effective, and Fun Approach to the Subject of Christian Education and Character Education to Improve the Learning Outcomes of the third-grade students in SD GMIM Manado."

\section{Theoritical Framework}

The lesson being taught using a conventional approach where the students required writing and listening only. The reason why most of the teachers are still using this conventional method is various, some of them said that it is because they don't have enough time to teach in class, limited resources to create an interesting learning environment, limited facilities, they don't have variety of teaching strategy and in the learning process, and the teacher usually don't pay attention with the learning habits of the students. For example, students use their feeling more often than their minds, that's why some of the students get scared of the teachers because they are afraid that if they come up with a wrong answer they will get scolded. Then, the students will not stand to focus to learn and they will struggle to concentrate on the lesson.

This situation and condition show that the learning process for these two subjects in Elementary School needs an active, innovative, creative, effective and fun approach. Using this approach will bring a great impact on the learning process of the students since it formulated carefully so that the learning material could reach the students and bring the expected result. According to Jauhar, active learning means the teacher should be actively and simultaneously makes the learning process in the classroom is more interesting. It's not only for the teachers, but the students also should take their part in the learning process. The participation of the teacher and students can be created by the creativity of the teacher when they give the questions to the students. On the contrary, the students creatively participated to answer and to open up their great ideas. The active learning could give a creative contribution to the students and it will bring an impact not only for the students but people around them as well. Innovative learning means that the teacher should create innovation with their knowledge to explore the different characteristics of each student so that they will be able to identify and to apply the new things according to the condition and ability to absorb the lesson from the students. It will bring a result where the students will be able to learn the lesson 
innovatively. Creative learning means that the teacher should be able to create various teaching methods according to the needs of the students, and it will cause the students to be more pro-active and have a critical way of thinking through the learning process. Effective learning means that the learning process brings a great impact both for the teacher and for the students. Therefore, the evaluation is needed at every end of the lesson. Fun learning means that the learning process could be enjoyed not only by the teacher but also by the students as well. Both the teacher and students need to feel comfortable and secure throughout the learning process. When the environment like this is created then the students could be motivated to continue to learning and find out the things that they don't understand in the first place [1].

Therefore, the AICEF approach can be used as one of the teaching strategies to liven up the learning environment to be more active, innovative, creative, effective and fun. Using this approach throughout the learning process, the teacher can connect the lesson with the contextual environment with the purpose to motivate the students to be able to develop their full potential by doing the various activities to develop their skills through learning and experimenting, discussing, role-playing, and at the same time, the teacher preparing the tools that will be needed to make the whole learning process becomes more interesting for the students.

The ideal learning motivation of the students can be reached using the AICEF approach since using this method will help the teacher to teach lessons easier and will well-received by the students. The teacher's responsibility when using this approach is they can use many sources and learning tools which are contextual with the situation and condition to create an interesting, fun, dan right on target learning environment [2].

\section{Methods}

This research is formed using the Classroom Action Research form by using the AICEF approach. This classroom action research is done through some cycles and by using the qualitative method to describe the activity of the students and teacher in the learning process. Therefore, this research is a descriptive classroom action research using the research design by Kemmis and Mc Taggar (Depdiknas 2005). Ever cycle is done through some steps: Planning, Action, Observation, and Reflection [3]. This research will be done at SD GMIM 1 Manado on their second semester in 2017/2018. The subject of this research is the 22 third-grade students in SD GMIM 1 Manado.

When collecting the data about the related variable there are various tools and technique that is used: a). observation is done as the learning process is running and the subjects of observation are the students and the teacher (observer) as the experiment occurs. b). The test is done to collect information about student comprehension of the given lesson. c). Documentation. This technique is done throughout the learning process by taking pictures of the students' activity during the experiment on the learning process. d). Field note. This technique contains the important things that occur during the learning process that could be used to complete the data that don't get recorded on the observation paper. According to Susilo, data analysis is an effort to summarize the data that has been collected in a reliable, accurate, reliable and correct manner [4]. Data analysis obtained through a combination of qualitative and quantitative data, like said Dadang Iskandar and Narsim. 
Data analysis techniques in classroom action research are relatively simple because they are only in the form of a percentage. However, PTK also collaborated with qualitative data obtained during the learning process. Therefore, the right data analysis technique in classroom action research is the percentage descriptive technique. This technique is used to describe quantitative and qualitative data that are interpreted in the form of a description [5].

The data that is collected from this research: Quantitative Data. It's collected from the early experiment and the last experiment. These data then processed and presented in the form of a percentage that counted by using a formula as follow:

\subsection{Quantitative Data}

a) The percentage of individual ability to absorb $=\frac{\text { Students score }}{\text { Maximum Score Question }} \times 100 \%$

Students are considered to pass their lessons passing grades individually if the percentage of their individual ability to absorb the lesson is bigger than $65 \%$

b) The classic learning completeness $=\frac{\text { Students scoretotal students who are passed }}{\text { Maximum Score Questiootal students in the classn }} \times 100 \%$

The class is considered to pass the classical learning completeness if more than $80 \%$ of students passed the passing grades.

\subsection{Qualitative Data}

The data collected then processed from analyzing all the data provided from various sources through observation of field notes and experiments.

\section{The Result and Discussion of the Research}

\subsection{The Result of this Research}

In the interest to get an objective result of the research then it should be started by doing an early experiment to all the students in third-grade. The early experiment could be the first step to apply the AICEF approach. The process as follows:

\section{a) The Result on Pre-Action Step}

The first thing to do on this pre-action step is doing the early experiment. The students are given 5 questions with multiple choices and they should do it individually. The goal is to discover the ability of the students to learn the lesson about toleration toward other people. The result of this early experiment showed that only one student who got the perfect score (100) and seven students got the 20 as the lower score from 22 students in the class. There were only 8 students who passed. The percentage of the classical ability to absorb the lesson was $50,45 \%$ and the percentage of classical completeness was $36,36 \%$. Through these results, the researcher concludes that the classroom action research method should be applied using the AICEF approach to the learning process of Christian Education for the third-grade students in SD GMIM 1 Manado. 
The next activity is to divide the students into three different groups. The students are divided according to their church denomination, their address and the result from the early experiment. Under this condition, the researcher is ready to apply the AICEF approach to the learning process.

\section{b) The Action Results in the First Cycle.}

The action step on the first cycle is done in the form of planning the observation and reflection. The lesson that is given is about toleration towards other people, then, followed with the final test. Through this final test, the lesson outcomes of the students can be seen.

The lesson outcomes of the students on the final test in the first cycle of classroom action research shown unsatisfying results. It's not as expected. Only 5 students got the highest score (100) and 1 student got the lowest score (30). Meanwhile, there were only 15 students who passed among the 22 students overall. Therefore, this result shows that the percentage of classical ability to absorb the lesson is $75,45 \%$ and the percentage of classical completeness is $68,16 \%$. It means that the average grades of classical ability to absorb didn't reach the minimum criteria by $65 \%$ as set by DSK. The completeness of classical learning on the first cycle has not to reach the expected percentage which is $80 \%$. The result of the analysis on that experiment showed that the students still find it difficult to focus on the lesson that is given to them and it makes them unable to understand the lesson well enough. For more clearly, it can be seen from the observation result of the activity of the students and teacher on the first cycle. The observation result in student activity has shown the percentage of $54,16 \%$. This indicates less, while, the observation result in teacher activity has shown the percentage of $66,66 \%$. This indicates well enough.

\section{c) The Action Results in the Second Cycle.}

The step of action on this second cycle is done in the form of planning the action of observation and reflection.

The activity of the learning process in Christian Education on this second cycle is done by using the AICEF approach. The final test on this second cycle is done to know the learning outcomes of the student. It shows that there is a good improvement in their results. This is proved by the outcomes as follows: 15 students got the highest score (100), 2 students got a lower score (60). Meanwhile, there are 20 students passed the test among the 22 students. Therefore, the percentage of the classical ability to absorb the lesson was $92,27 \%$ and the percentage of classical completeness was $90,90 \%$. It means that the average grades for the classical ability to absorb the lesson have reached the target indicator which is $80 \%$ and the analysis result of student activity shows the percentage of $98,83 \%$. This indicates very well. At the same time, the analysis result of teacher activity shows a percentage of $91,66 \%$. This also indicates very well. These results have shown that there is an improvement from the action on the first cycle to the action on the second cycle.

On the action of the second cycle, the learning outcomes of the student show an improvement compared to the first cycle. Therefore, the AICEF approach could be applied to the teaching of Christian Education lesson for the students in third-grade in SD GMIM 1 Manado. The improvement of the learning outcomes of the students caused by the variety of learning methods that helped the students to be more engaged in learning the lesson. The second cycle pictured the enthusiasm of the students to participate in the various learning process such as discussion, demonstration, and quizzes. Moreover, the improvement of the 
result outcomes also affected by the activity of the teacher. By figuring out the weakness of the teacher on the action step in the first cycle then the teacher will be able to revise it by using a variety of learning tools, approaching the students with kindness, giving positive feedbacks and encouraging all students to be more engaging in the learning process.

\subsection{Discussion}

The AICEF approach could be categorized as an important teaching strategy since its goal is to make the lesson that is taught by the teacher will be absorbed by the students without so much effort, easier to understand, and can be applied by the students and hopefully impacted their character building in positive ways. Using the AICEF approach helps the learning process of Christian Education lessons become more meaningful for the students. Basically, according to Werner. G. Graendorf [6] PAK learning is a teaching and learning process that is based on the Bible, centered on Christ. As the lesson becomes meaningful for the students then it can improve their learning outcomes as well. This method requires the teacher to be more prepared so that it will bring significant changes in the learning process. Tabrani Rusyan in Trianto [7] explained that great teaching is a result of great preparation. In order to develop the quality of teaching that has an impact on the learning outcomes of the students, then the teacher should give a chance for the students to build their self-potentials(3). Related to this, Tessier in Amri and Lif Khoiru [8] said that the students should actively participate in the learning process. The participation of the students proves that the students have the independency to experience the enjoyable learning process. With the media $\mathrm{i}$ tis hoped that students will be more motivated, student imaginations are stimulated, feelings are touched and the deep impressions. Student attention to learning material increases so that it can update student learning outcomes [9].

The research process with the AICEF approach started with an early experiment. The purpose is to find out how far the basic knowledge of the students in terms of learning Christian Education lessons. Understanding the ability of the students will be a great foundation for the researcher to design the teaching method using the AICEF approach. The early test that was given showed that the students didn't understand the concept of the lesson. It was because the students didn't focus on the learning process, but instead, they were busy talking to each other, bugging their classmates and some of them just did what they want to do. To overcome this, the teacher should teach well by creating an interesting learning environment so the students will motivate to take part in the learning process.

The result of the observation on the first cycle shows that the students were unable to work in a group and some of them were still passively participating in the learning process. Some of them didn't even brave enough to answer the question given to them correctly. On the contrary, some students were brave enough to answer but they didn't do it orderly and politely. To prevent this behavior in the next cycle then the teacher prepares various interesting teaching methods so the students will be more enthusiast in the learning process.

The action on the first cycle gave a hint for the second cycle that the teacher used one of the AICEF approaches in this case playing a video that contains the subject of the lesson, letting the students discuss in group, story-telling, giving quiz and play-role and evaluation. This method divided into a few minutes and ended at the exact time. All the methods contain the lesson about Christian Education. Using this method, the students seem to enjoy and able to concentrate on their lesson and because of it, the action on this second cycle showed a significant improvement compared to the first cycle. The result of the observation of teacher activity is considered improved since the teaching process was optimized by the teacher. The 
teacher got used to create an active, innovative, and effective and fun learning environment by using various media and sources. It is different compared to the conventional teaching method that was used before the experiment.

Based on the result of the observation above, the learning outcomes of the students show improvement. It can be seen through the score that the students get when they were answering the given question. The final result shows that the percentage of the classical ability to absorb the lesson is $92,27 \%$ and the percentage of classical completeness is $90,90 \%$. It means that the average grades of the ability to absorb the lesson have reached the target indicator of $80 \%$ and on the other hand, the result of the analysis of student activity shows the percentage of $98,83 \%$. Meanwhile, the result of the analysis of teacher activity shows the percentage of $91,66 \%$. With this result, it can be concluded that this research succeeds.

This research proved that the AICEF approach is able to create a new learning environment to help the students focus and enjoy the learning process, in this case, learning the Christian Education lesson. The most important thing to remember is that the lesson should be able to receive by the students according to their needs. AICEF approach could motivate the students to focus on their study and to get better learning outcomes. The role of the teacher is should be considered as well. The teacher should improve their skill and competency as they are using the AICEF approach so that the students will always get interested to learn and understand the lesson and surely it will bring a great impact on their lives.

\section{Conclusion and Recommendation}

Based on the observation and analysis above, it can be concluded:

a) The result of the teacher observation on the first meeting on the first cycle was $58,33 \%$ and the second meeting was $66,66 \%$. In the second cycle, it is improved to $87,5 \%$ on the first meeting and on the second meeting it is raised to $95,83 \%$.

b) The result of the student observation on the first meeting on the first cycle was $54,16 \%$ and the second meeting was $62,5 \%$. In the second cycle, it is improved to $87,5 \%$ on the first meeting and on the second meeting it is raised to $95,83 \%$.

c) On the pre-action step, the percentage of the classical ability to absorb the lesson only $54,45 \%$ and the percentage of classical completeness only $36,36 \%$. The percentage of the classical ability to absorb the lesson on the action step in the first cycle is improved to $75,45 \%$ and the percentage of the classical completeness is $68,16 \%$, and then, on the second cycle it improves to $92,27 \%$ and with the classical completeness is $90,90 \%$. As it's been said and done, it can be concluded that the application of the AICEF approach to the subject of Christian Education and Character Education is verified to improve the learning outcomes of the third-grade students in SD GMIM I Manado.

According to the outcomes of this research, there will be some recommendations as follows:

a) It's recommended that the teacher of Christian Education should be more involved in media teaching training.

b) It's necessary for schools to provide facilities that needed as learning tools for Christian Education lessons.

c) The curriculum of Christian Education that used by SD GMIM 1 Manado should be studied and developed. 


\section{References}

[1] Mohamad Jauhar (2011), Implementasi PAIKEM dariBehavioristiksampaikonstruktivistik, Jakarta: Prestasi Pustaka, 158-170

[2] Asmani (2013), tips 7 aplikasi PAIKEM - MenciptakanMetodePembelajaran yang Efektif dan BerkualitasYogyakarta: DIVA Press, 59

[3] Arikunto (2010), ProsedurPenelitianSuatuPendekatanPraktek.Jakarta :RinekeCipta, 131

[4] Susilo Herawati (2011). Penelitian Tindakan Kelas sebagai Sarana PengembanganKeprofesionalan Guru dan Calon Guru. Malang: Bayumedia Publishing, 100

[5] Dadang, Iskandar dan Narsim (2015). Penelitian Tindakan Kelas dan Publikasinya Untuk Kenaikan Pangkat dan Golongan Guru dan Pedoman Penulisan PTK bagi Mahasiswa. Cilacap: Ihya Media, 72

[6] Werner C (1981). Graendorf, Introduction to Biblical Christian Education, Chicago: Moody Press, 16.

[7] TabraniRusyandalamTrianto (2007), Model-Model PembelajaranInovatif. Jakarta :Prestasi Pustaka, 95

[8] Tessier dalam Amri dan LifKhoiru (2010), Proses PembelajaranKreatif Dan InovatifDalam Kelas. Jakarta : PT. PrestasiPustakaraya, 110

[9] Ruth Lautfer (1993), PedomanPelayanan Anak. Malang : Yayasan Persekutuan PekabaranInjil, 134 